\title{
НАУКОВО-МЕТОДИЧНЕ ЗАБЕЗПЕЧЕННЯ РЕАЛІЗАЦІї ЗМІСТУ НАВЧАННЯ ДІТЕЙ 3 КОМПЛЕКСНИМИ ПОРУШЕННЯМИ РОЗВИТКУ
}

\author{
Наукова доповід ь на засіданні Президії НАПН України 18 лютого 2021 р. \\ https://doi.org/10.37472/2707-305X-2021-3-1-2-2
}

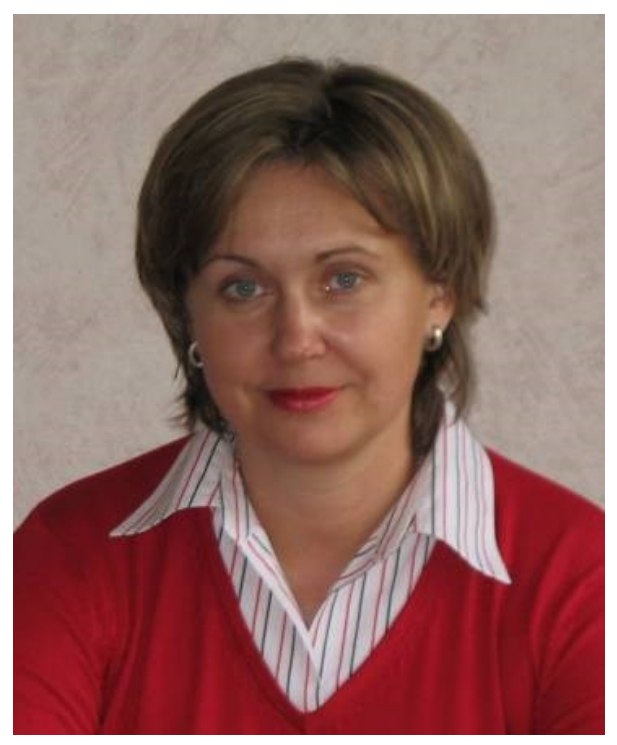

ЧЕБОТАРЬОВА

\section{Олена Валентинівна}

кандидат педагогічних наук, старший науковий співробітник, завідувач відділу освіти дітей з порушеннями інтелектуального розвитку Інституту спеціальної педагогіки і психології імені Миколи Ярмаченка Начіональної академії педагогічних наук України, м. Київ, Україна

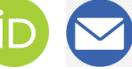

Анотачія. Представлено основні результати прикладного дослідження "Науково-методичне забезпечення реалізації змісту навчання дітей з комплексними порушеннями розвитку», яке виконувалось вченими відділу освіти дітей з порушеннями інтелектуального розвитку Інституту спеціальної педагогіки і психології імені Миколи Ярмаченка НАПН України впродовж 20182020 рр. Презентовано розроблені та апробовані на практищі науково-методичні посібники, підручники, комплекти типових освітніх і корекційно-розвивальних програм, діагностичні матеріали для вивчення особливостей розвитку та навчання дітей із інтелектуальними та комплексними порушеннями. Особливу увагу приділено впровадженню результатів дослідження в практику спеціальних та інклюзивних закладів загальної середньої освіти. Привернуто увагу до активної співпраці відділу освіти дітей з порушеннями інтелектуального розвитку Інституту спеціальної педагогіки і психології імені Миколи Ярмаченка НАПН України та МОН України щодо розроблення навчально-методичного забезпечення навчання дітей із інтелектуальними та комплексними порушеннями розвитку відповідно Концепиії Нової української школи. Акцентується увага на результатах співпраці у міжнародному проєкті «Перспектива 21/3» щодо соціалізації учнів із порушеннями інтелектуального розвитку, співробітництва з громадськими батьківськими організаціями, популяризації науково-практичних результатів на курсах підвищення кваліфікації педагогічних працівників та ін. Висловлено пропозиції щодо подальщих інноваційних пошуків у сорері освіти дітей із порушеннями інтелектуального розвитку, охоплюючи ранній, дошкільний і молодший шкільний вік.

Ключові слова: комплексні порушення розвитку; порушення інтелектуального розвитку; зміст освіти; навчально-методичне забезпечення; відділ освіти дітей з порушеннями інтелектуального розвитку; Інститут спеціальної педагогіки і психології імені Миколи Ярмаченка НАПН України.

Дослідження за темою «Науково-методичне забезпечення реалізації змісту навчання дітей з комплексними порушеннями розвитку», яке виконувалося упродовж 2018-2020 рр., спрямовувалось на реалізацію законів України «Про освіту» і «Про повну загальну середню освіту», Концепції «Нова Українська школа», Конвенції про права осіб з інвалідністю тощо.

Основними завданнями, що розв'язувалися вченими відділу освіти дітей з порушеннями інтелектуального розвитку Інституту спеціальної педагогіки і психології імені Миколи Ярмаченка Національної академії педагогічних України в 2018-2020 рр., були:

- теоретичне узагальнення та інтерпретування існуючого науково-методичного забезпечення реалізації змісту навчання 


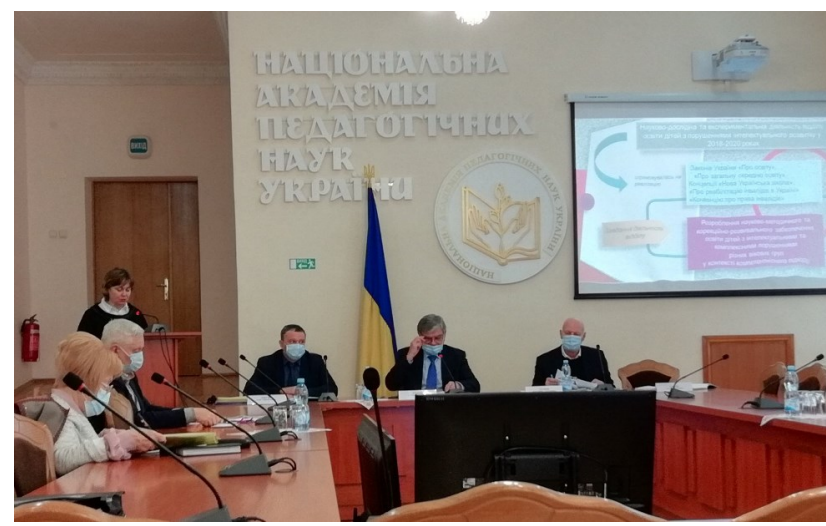

дітей із інтелектуальними та комплексними порушеннями розвитку з позицій розуміння механізмів складних порушень;

- визначення методичних основ реалізації змісту корекційно-розвивального навчання дітей 3 інтелектуальними та комплексними порушеннями розвитку;

- розроблення та впровадження оновленого навчально-методичного забезпечення;

- апробація результатів прикладного дослідження у практиці діяльності спеціальних закладів загальної середньої освіти та закладів із інклюзивним навчанням;

- моніторинг упровадження результатів наукового дослідження.

Усі завдання протягом звітного періоду відповідно до технічного завдання виконано:

здійснено аналіз стану освіти дітей із інтелектуальними та комплексними порушеннями у контексті запровадження реформ Нової української школи (НУШ) та визначено основні тенденції ії реалізації. Основними інноваційними освітніми напрямами $€$ розроблення адаптованого змісту шкільної освіти учнів та розширення спектра корекційно-розвивальних технологій їхнього навчання та психолого-педагогічного супроводу. Це забезпечить різноманітні форми освітньої інтеграції таких школярів засобами компенсаторного, корекційно-розвивального, компетентнісно орієнтованого навчання з урахуванням індивідуальних

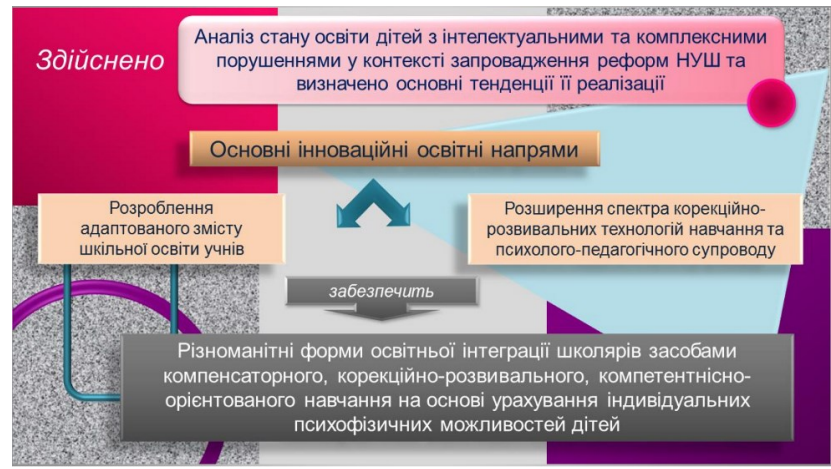

психофізичних можливостей дітей (розвитку інтелектуальної, сенсомоторної, мовленнєвої, особистісної сфер).

Обгрунтовано модель компетентнісної освіmи молодших школярів із інтелектуальними порушеннями, що передбачає організаційну (форми освітніх закладів), змістову (основні освітні галузі знань і предмети навчання) та технологічну (корекційно-розвивальні напрями та технології їх реалізації) складові з урахуванням: особливостей пізнавальної, сенсомоторної, мовленнєвої діяльності учнів; запобігання вторинним порушенням пізнавального розвитку; формування здатності застосовувати отримані знання, уміння і навички комунікації та взаємодії у різних сферах життєдіяльності.

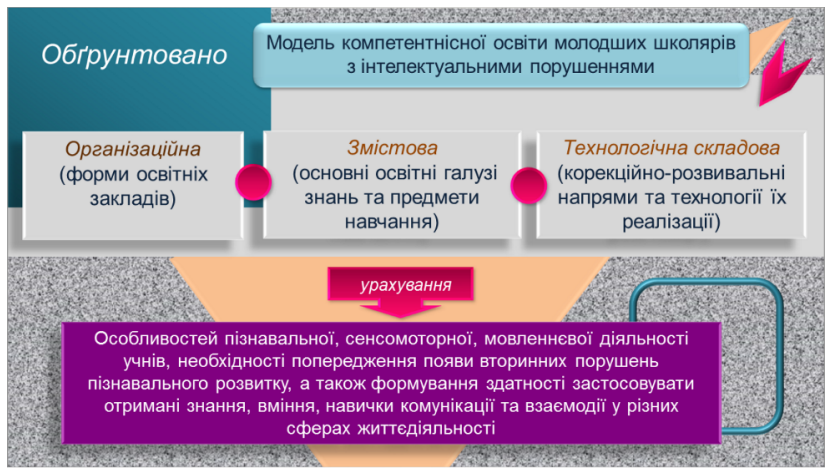

Модернізовано зміст навчання дітей з інтелектуальними порушеннями шляхом розроблення Tипової освітньої програми для 1-4 класів, що містить орієнтовний зміст навчального матеріалу, опис предметно орієнтованих і життєвих компетентностей для дітей із інтелектуальними порушеннями. Інноваційне програмне забезпечення розроблено на основі провідних позицій компетентнісно орієнтованої моделі навчання з огляду на Концепцію НУШ. Програма є базисом для розроблення робочих навчальних програм закладів, де отримують освіту діти з інтелектуальними порушеннями. У програмі закладено диференційований зміст навчання для дітей з більшими та меншими пізнавальними можливостями (легкий і помірний ступінь інтелектуального порушення). Принцип доцільного відбору змісту базового навчання дав змогу розробити зміст навчання 3 української мови (навчання грамоти), читання, математики, трудового навчання, інтегрованих курсів «Я досліджую світ», «Мистецтво», «Технології», що сприятиме формуванню педагогічної компетентності вчителів початкової ланки, які здійснюють освіту дітей із інтелектуальними порушеннями. 


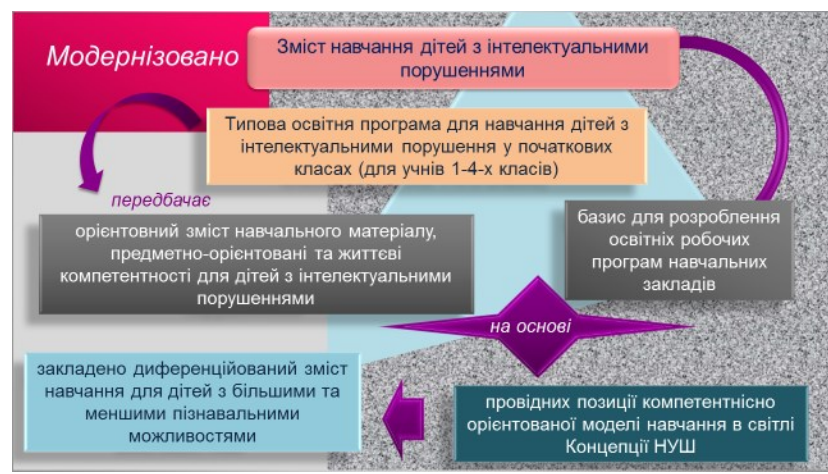

Розроблено та апробовано корекційнорозвивальні технології навчання та підтримки дітей із комплексними порушеннями розвитку, які мають ураження інтелектуальної, сенсомоторної, мовленнєвої, особистісної сфер розвитку. Основні напрями корекційно-реабілітаційних технологій у роботі з дітьми передбачають такі види розвитку: психосоціальний (пізнавальний, сенсорний, емоційно-ціннісний); мовленнєвий (розвиток мовлення та навичок комунікації, зокрема з використанням альтернативних засобів); соціально-побутовий (розвиток соціальнопобутових навичок, соціальної поведінки, соціальної взаємодії), лікувально-оздоровчий (розвиток фізичної сфери, координації рухів, профілактично-оздоровчі заходи); музичноритмічний (психоемоційний, психомоторний, естетичний).

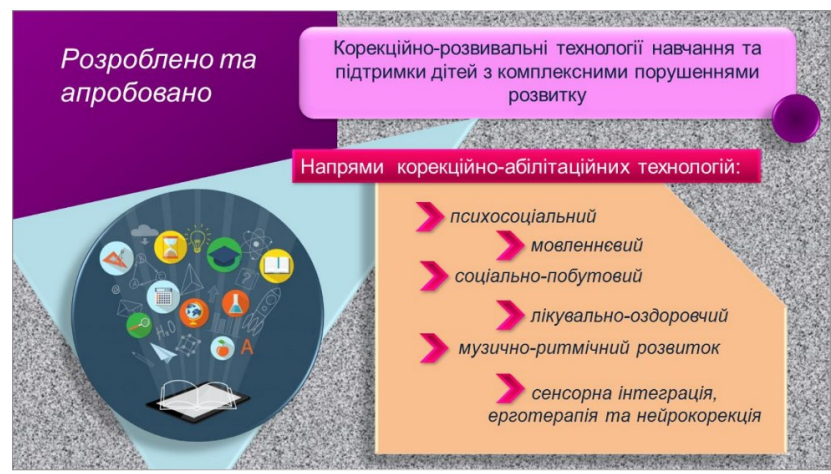

Розроблено сучасне навчально-методичне забезпечення освіти дітей з інтелектуальними порушеннями, що передбачає використання інноваційних компетентнісно орієнтованих освітніх технологій відповідно до реалізації Концепції НУШ в умовах спеціального та інклюзивного навчання та базується на удосконаленні пізнавальної, комунікативно-мовленнєвої, психомоторної, особистісної сфер розвитку молодших школярів. Корекційно-розвивальне забезпечення навчання молодших школярів із інтелектуальними порушеннями спрямовано на розвиток пізнавальної діяльності, розвиток та корекцію рухової сфери, сенсорних функцій, мовлення, розширення уявлень про навколишній світ, психокорекцію особистості. В основу авторських розробок покладено сучасне розуміння особливостей розвитку молодших школярів із порушеннями інтелектуального розвитку, формування у них ціннісних позицій, поглядів, переконань, мотивів, опанування способів діяльності, вироблення адекватної моделі соціальної поведінки, що забезпечується насамперед у процесі спеціального навчання та психолого-педагогічного супроводу.

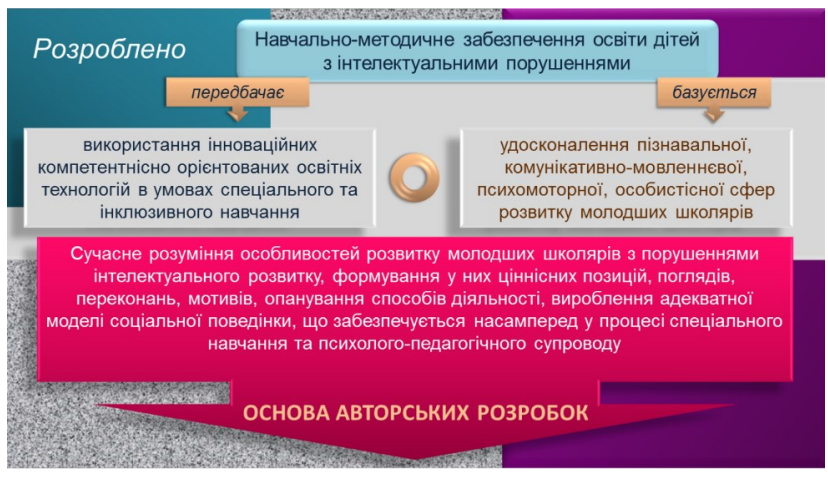

Удосконалено критерії оцінювання навчальних досягнень учнів початкових класів із порушеннями інтелектуального розвитку відповідно до Концепції НУШ і вперше розроблено критерії оцінювання навчальних досягнень учнів 510 класів, що представлено як інструментарій підтримки і заохочення позитивних змін у знаннях, уміннях, мотиваціях і реальній поведінці школярів старшої школи. Визначено основні функції представлених критеріїв: соціальну, мотиваційну, діагностичну, корекційну, розвивальну, виховну. У Критеріях уперше запропоновано зразок свідоцтва досягнень учнів із порушеннями інтелектуального розвитку початкової школи, що складається з характеристики їхніх особистих досягнень учнів та оцінювання предметних компетентностей.

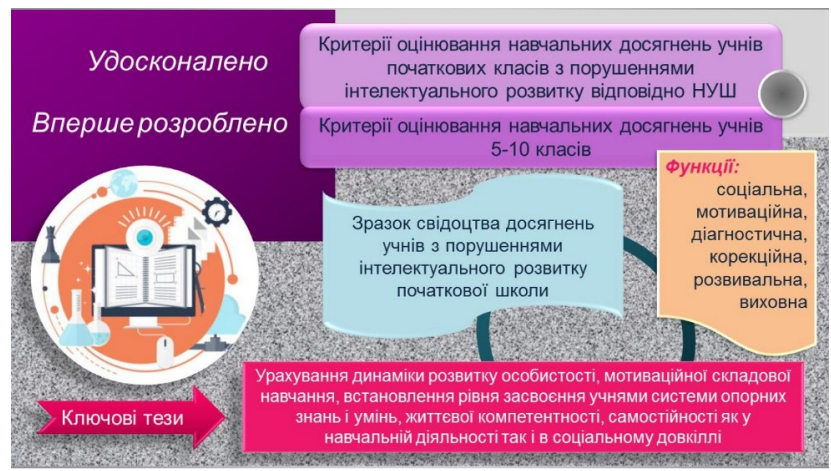

Для оцінювання учнів пропонується рівнева система: «має значні успіхи», «демонструє поміт- 
ний прогрес», «досягає результату з допомогою вчителя», «потребує значної уваги і постійної допомоги вчителя».

Ключовими тезами під час розроблення критеріїв $є$ урахування динаміки розвитку особистості, мотиваційної складової навчання, встановлення рівня не тільки засвоєння учнями системи опорних знань і умінь, а й їхньої життєвої компетентності, самостійності як у навчальній діяльності, так і в соціальному довкіллі.

Розкрито специфіку діагностичної діяльності корекційного педагога у роботі з дітьми з комплексними порушеннями розвитку, що передбачає комплексне обстеження дітей як прогностичну основу для подальшої діяльності педагогів із дітьми такої категорії. Охарактеризовано зміст та алгоритм процесу визначення психофізичного розвитку дітей з комплексними порушеннями розвитку (порушення опорно-рухового апарату та інтелекту) раннього, дошкільного та молодшого шкільного віку. Висвітлені особливості діагностичного оцінювання розвитку передбачають урахування рівня сформованості соціально-адаптивних навичок, що виявляються у дієвості знань, умінь і навичок, мотивації щодо успішного засвоєння різних видів діяльності та сприяють соціальній адаптації та інтеграції дітей у суспільство. Формування поліфункціональної компетентності корекційного педагога розглядається як умова посилення корекційно-діагностичного спрямування освітньо-корекційного процесу, зосередження педагогічної уваги на особистості дитини як суб'єкті навчання, виховання та розвитку.

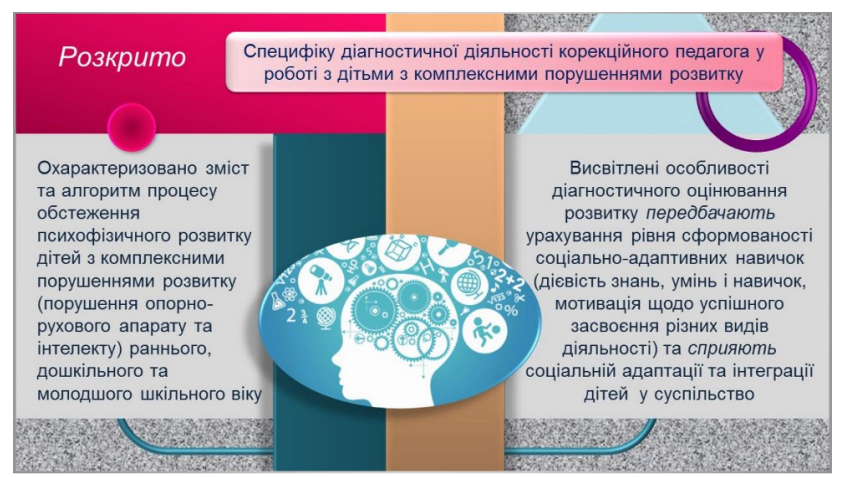

Розроблено методичне забезпечення психолого-педагогічного супроводу дітей із інтелектуальними порушеннями та їхніх родин, що забезпечується через реалізацію корекційноадаптаційних технологій навчання, алгоритм індивідуального освітнього маршруту та індивідуальної програми розвитку, організаційнопедагогічне забезпечення корекційно- розвивального освітнього середовища. Представлені технології спрямовані на розвиток у дітей мовлення, ігрової, трудової, самообслуговуючої діяльності, сенсорного, статевого виховання, соціально-побутової адаптації, формування здоров'язбережувальних навичок, математичних і природничих уявлень. В основу авторських розробок покладено сучасне розуміння особливостей розвитку дітей із порушеннями інтелектуального розвитку, формування у них ціннісних позицій, поглядів, переконань, мотивів, опанування способів діяльності, вироблення адекватної моделі соціальної поведінки, що забезпечується насамперед у процесі спеціального навчання і психологопедагогічного супроводу.

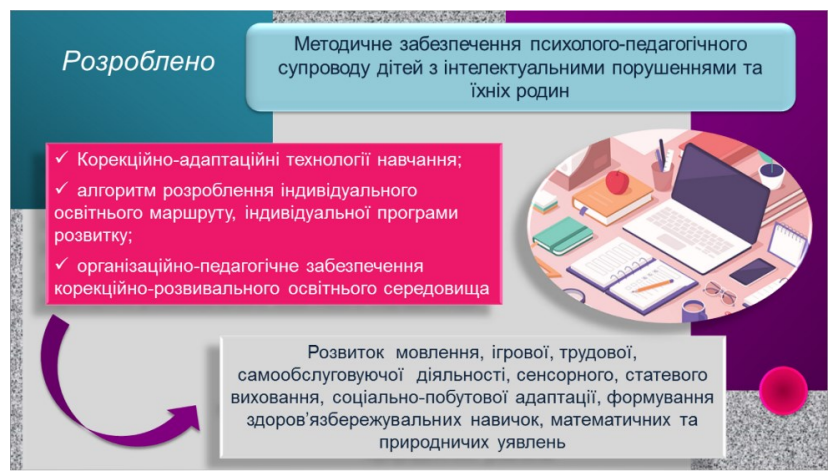

Обгрунтовано дидактичні та методичні підходи щодо навчання дітей із інтелектуальними порушеннями в умовах дистанційного навчання, що передбачають: доцільну організацію та методичний супровід навчання дітей у домашніх умовах; покрокову інструкцію щодо адаптації та подачі навчального матеріалу; важливі корекційні прийоми для дистанційного навчання учнів, які мають різні інтелектуальні можливості. Представлено покрокові рекомендації педагогам і батькам щодо оптимального навчання, виховання та розвитку дітей із інтелектуальними порушеннями на основі дидактичних ігор та вправ, корисних онлайн-ресурсів, які сприятимуть психосоціальному розвитку дітей в нових умовах навчання.

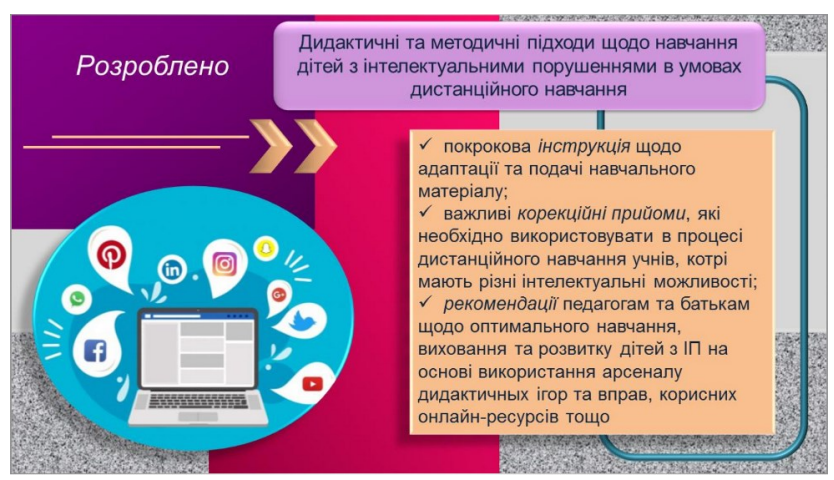


Розроблено сучасні підручники для учнів із порушеннями інтелектуального розвитку щодо імплементації компетентнісного та особистісно орієнтованого підходу через надання відповідним методикам психокорекційної роботи детермінуючої ролі у процесі опанування основ галузевих наукових знань, що дає змогу зробити вагомий внесок у теорію підручникотворення. Підручники розроблено відповідно до технічних і змістових вимог оформлення, які враховують особливості розвитку та освітні потреби учнів із порушеннями інтелектуального розвитку («Українська мова», «Математика», «Я досліджую світ», «Трудове навчання»).

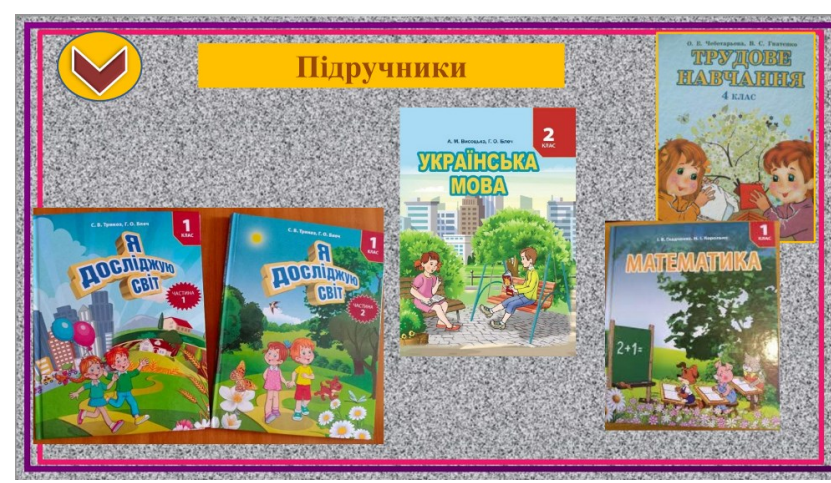

Аналіз результатів науково-дослідної та експериментальної діяльності засвідчив, що реалізація оновленого науково-методичного та корекційнорозвивального забезпечення освіти дітей з інтелектуальними та комплексними порушеннями розвитку сприятиме ефективному процесу компетентнісного навчання школярів із різним ступенем порушення інтелектуального розвитку.

У дослідженні використано такі методи, як психолого-педагогічний експеримент, аналіз та узагальнення науково-теоретичних та експериментальних даних, спостереження, моделювання освітнього процесу.

За результатами дослідження згідно з тематичним планом і технічним завданням підготовлено до друку і опубліковано 19 наукових праць, серед яких: монографія (розділ) - 1, посібники для батьків - 4, навчально-методичні посібники - 7, методичні рекомендації - 1, навчальні програми - 4, комплекти корекційно-розвиткових програм - 2, 67 публікацій (статей у наукових фахових виданнях - 33, матеріалів конференцій - 19).

Результати виконання наукового дослідження репрезентовано у:

- розділі монографрії «Сучасний стан та загальні тенденції розвитку освіти осіб з особливими освітніми потребами в Україні: від інституціаліза- ції до інклюзії» (розділ: «Освіта осіб з інтелектуальними порушеннями»);

- навчально-методичних посібниках, рекомендованих МОН України до використання у роботі 3 дітьми 3 особливими освітніми потребами: «Корекційно-розвивальні технології навчання дітей з комплексними порушеннями розвитку», «Критерії оцінювання навчальних досягнень учнів 5-10 класів з порушеннями інтелектуального розвитку», «Критерії оцінювання навчальних досягнень учнів початкових класів з порушеннями інтелектуального розвитку», «Особливості реалізації компетентнісного підходу в освіті дітей з інтелектуальними порушеннями», «Психологопедагогічний супровід навчання дітей з інтелектуальними порушеннями», «Порадник батькам: практичні рекомендації під час дистанційного навчання дітей з інтелектуальними порушеннями»;

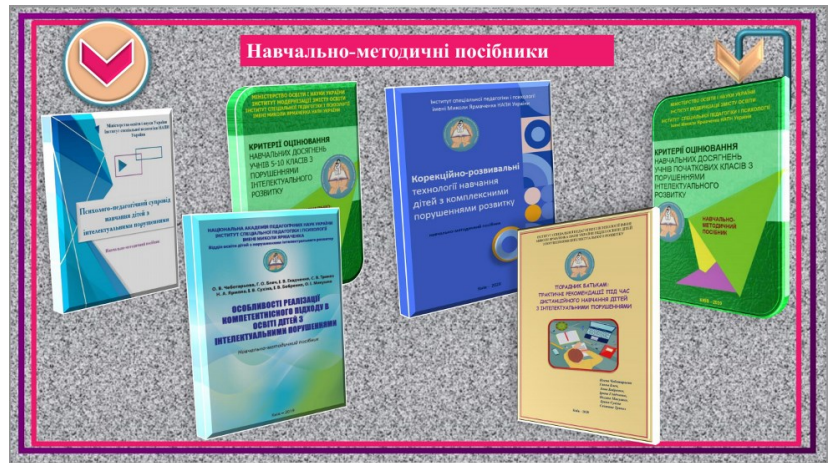

- комплекті посібників для батьків: Серія «ннклюзивне навчання» за нозологіями: «Дитина із церебральним паралічем», «Дитина із порушенням інтелектуального розвитку», «Дитина із синдромом Дауна», «Гіперактивна дитина»;

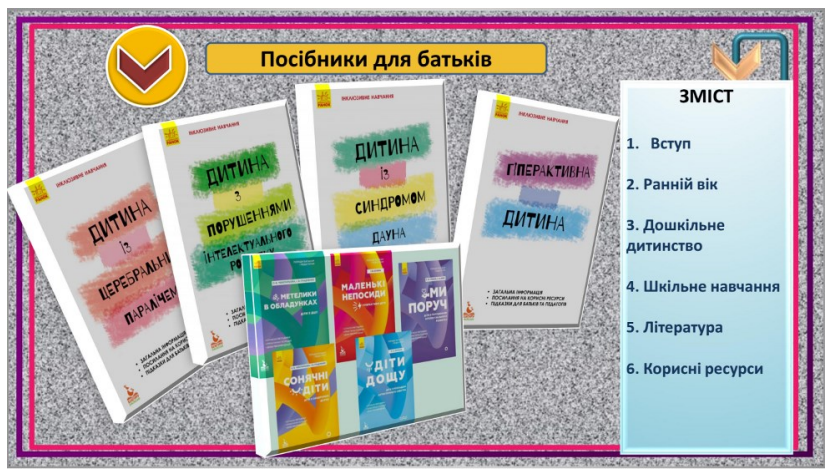

- методичних рекомендаціях «Основи діагностичної діяльності корекційного педагога в роботі з дітьми з комплексними порушеннями розвитку»;

- навчальних програмах, рекомендованих МOH України: Типова освітня програма початкової освіти спеціальних закладів загальної серед- 


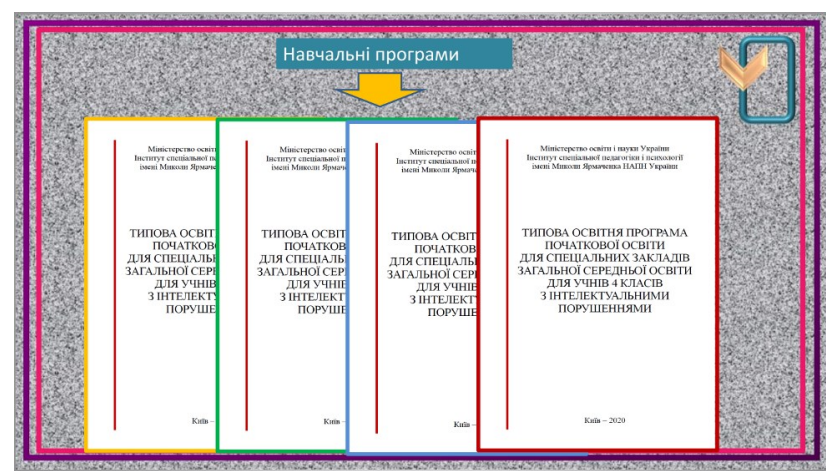

ньої освіти для учнів 1, 2, 3, 4 класів з інтелектуальними порушеннями;

- комплектах корекційно-розвиткових програм, рекомендованих МОН України: Комплект корекційно-розвиткових програм для 1-4 класів для спеціальних закладів загальної середньої освіти для дітей з інтелектуальними порушеннями: Програми з корекційно-розвиткової роботи «Азбука творчості», «Цікавий світ Монтессорі», «Розвиток психомоторики та сенсорних процесів», «Барабанотерапія», «Театральна логоритміка», «Розвиток мовлення», «Розвиток мовлення $з$ використанням методики Тан-Содерберг», «Лікувальна фізкультура», «Острівець здоров'я» «Музичні краплинки»; Комплект корекційнорозвиткових програм для 1-4 класів для спеціальних закладів загальної середньої освіти для дітей з порушеннями опорно-рухового апарату: Програма 3 корекційно-розвиткової роботи «Корекція розвитку» (базова), «Лікувальна фізична культура», «Світ Монтессорі», «Корекційна ритміка» та ін.

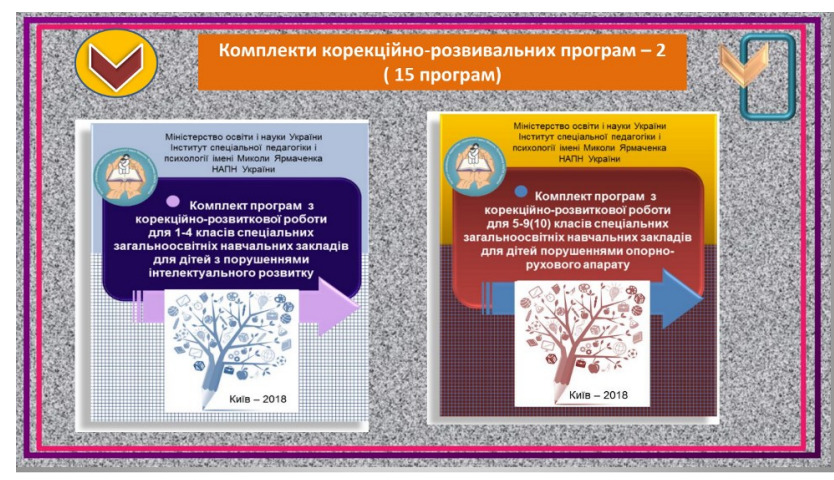

Про успішне впровадження і моніторинг ефективності результатів проведеного наукового дослідження свідчить наявність 11 угод про співпрацю між відділом і закладами освіти; 34 довідки та 46 сертифікатів, які підтверджують апробацію отриманих під час дослідження експериментальних даних. Отримані результати оприлюднено під час виступів виконавців дослідження на 170 масових заходах, з яких 74 - міжнародного рівня.

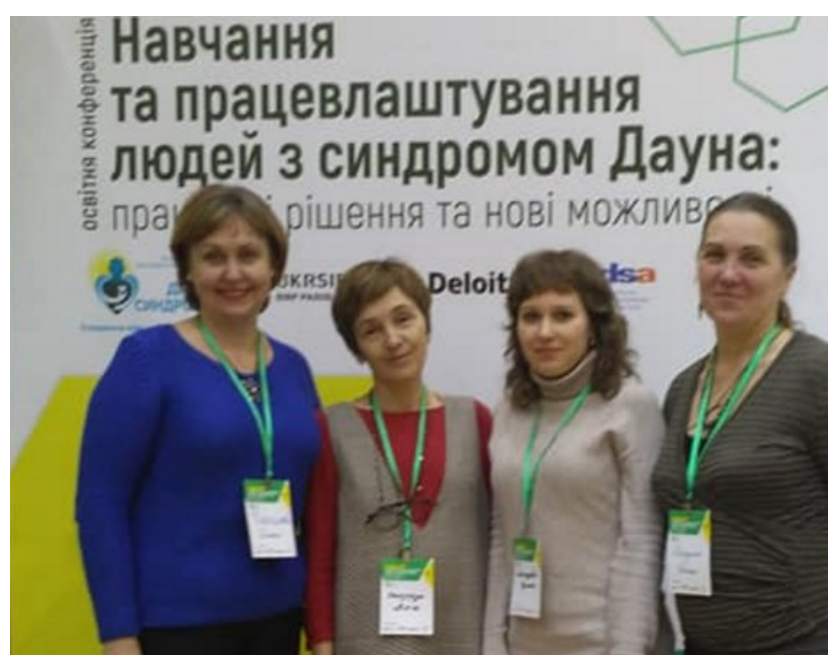

Про затребуваність результатів наукового дослідження «Науково-методичне забезпечення реалізації змісту навчання дітей з комплексними порушеннями розвитку» свідчать близько 50 тис. завантажень ресурсів з Електронної бібліотеки Національної академії педагогічних наук України, які представлено у вільному доступі.

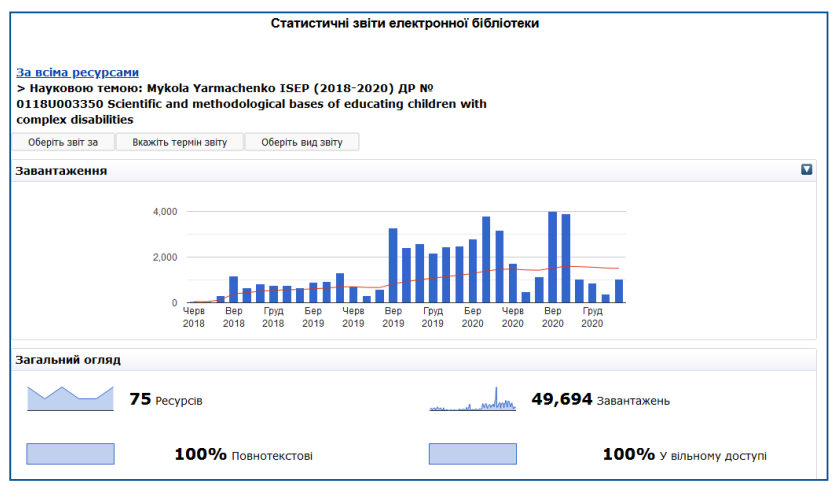

Досить представницьким $є$ перелік об'єктів упровадження, а це усі спеціальні загальноосвітні навчальні заклади України для дітей з порушеннями інтелектуального розвитку - 124, порушеннями опорно-рухового апарату - 15 (спеціальні школи №№ 10, 15, 16, 17, 26 м. Києва, ЗДО № 9 компенсуючого типу м. Києва, № 569 м. Києва; НРЦ «Шанс» м. Дніпро, НРЦ «Колосок» м. Дніпро;

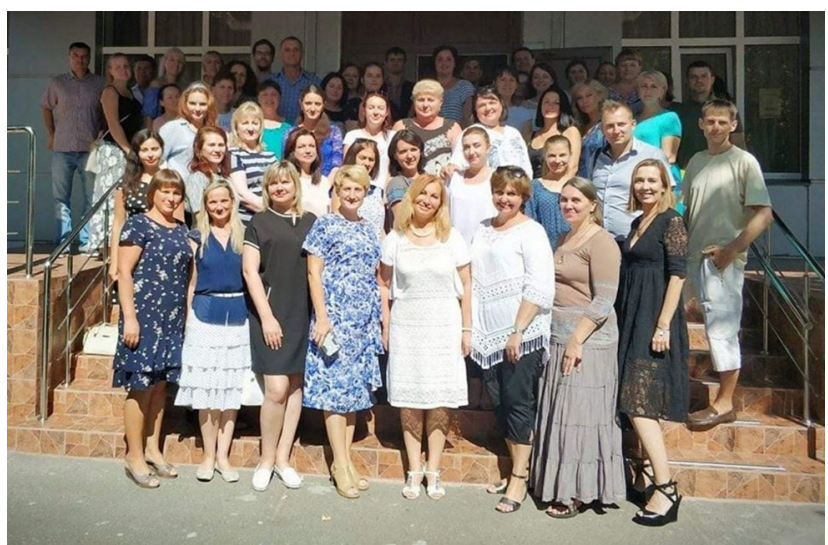


НРЦ «Гармонія» м. Борислав; спеціальна школа № 19 м. Біла Церква тощо); інші установи, підприємства, організації - 26 (Центри соціальнопсихологічної реабілітації Оболонського р-ну м. Києва, ІРЦ Печерського р-ну м. Києва, м. Дніпра; Полтавський НРЦ тощо).

Результати наукового дослідження, усі масові заходи регулярно розміщуються на вебсайтах МОН України, Електронної бібліотеки НАПН України, Інституту спеціальної педагогіки і психології імені Миколи Ярмаченка НАПН України; сторінках відділу освіти дітей з порушеннями інтелектуального розвитку та Інституту у ФБ, вебсайтах та вебсторінках експериментальних закладів освіти.

Вагомим аспектом впровадження результатів діяльності відділу є співпраця з Міністерством освіти і науки України, яка полягає у долученні

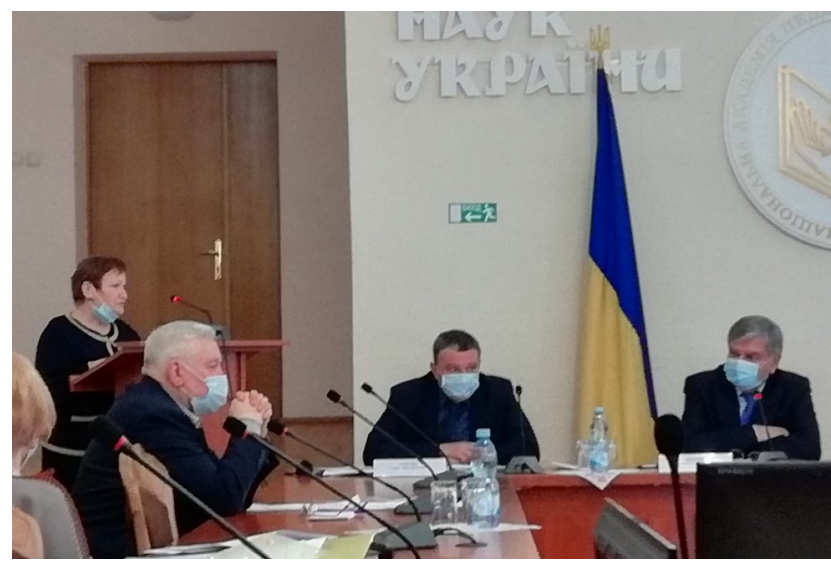

вчених відділу до творчих груп із розроблення корекційно-розвиткових програм для дітей з порушеннями інтелектуального розвитку та опорнорухового апарату, типових освітніх програм, критеріїв оцінювання навчальних досягнень, нарад для директорів спеціальних закладів освіти, проєктів щодо розроблення спрощеного читання для осіб з інтелектуальними порушеннями, презентації досягнень вітчизняної науки та практичного досвіду.

Слід відзначити, що за результатами наукового дослідження отримано відзнаки міжнародних спеціалізованих виставок, а вчених відділу нагороджено почесними грамотами Інституту, керівника теми О.В. Чеботарьову - відзначено медаллю «Народна шана українським науковцям» 2018-2019 рр. Міжнародної Академії МАРТІС «Золота Фортуна».

Результати дослідження активно впроваджуються на курсах підвищення кваліфікації педагогічних працівників за освітньо-професійною програмою «Психолого-педагогічні технології в освіті

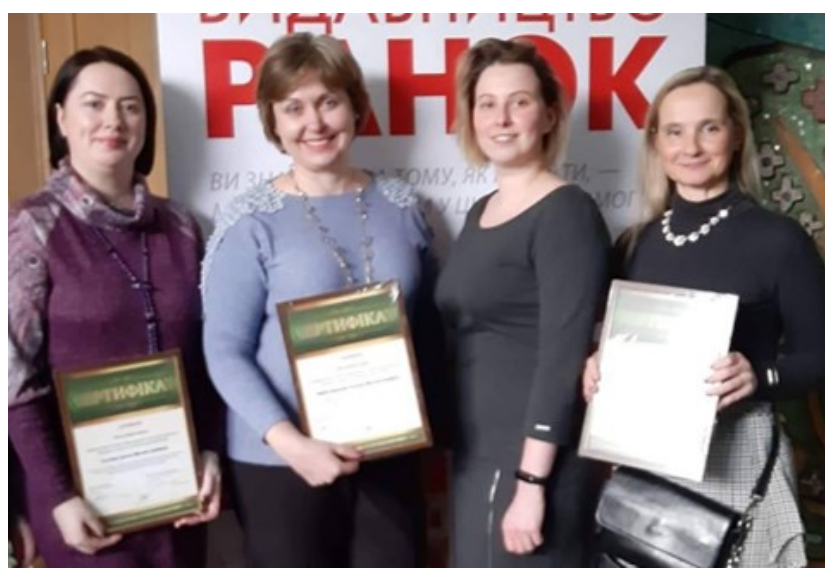

дітей 3 особливими освітніми потребами» (30 год. онлайн) та програмою «Сучасні технології навчання та формування життєвої компетентності учнів з інтелектуальними та комплексними порушеннями розвитку», організованих Інститутом спеціальної педагогіки і психології імені Миколи Ярмаченка НАПН України.

Важливим напрямом міжнародної співпраці $\epsilon$ продовження наукового супроводу проєкту Перспектива 21/3 на базі спеціального закладу № 26 у спеціальних класах «Радість». Співробітники проводять круглі столи, беруть участь у науково-методичних семінарах, міжнародних конференціях. Співпраця створила основу для написання із керівником проєкту (Арендою Василенко-ван де Рей) навчально-методичного посібника для батьків та фахівців «Дитина із синдромом Дауна». Реалізація проєкту підтримується: всеукраїнською благодійною організацією «Даун Синдром» (Україна), «Down Syndrome International Education» (Велика Британія), Спеціалізованою школою «De Rank» (Нідерланди), OGO, організацією, яка підтримує розвиток спеціального навчання у країнах Східної Європи (Нідерланди), Педагогічним університетом «Driestar Educatief» (Нідерланди), Культурно-просвітницьким Центром сприяння розвитку християнської куль-

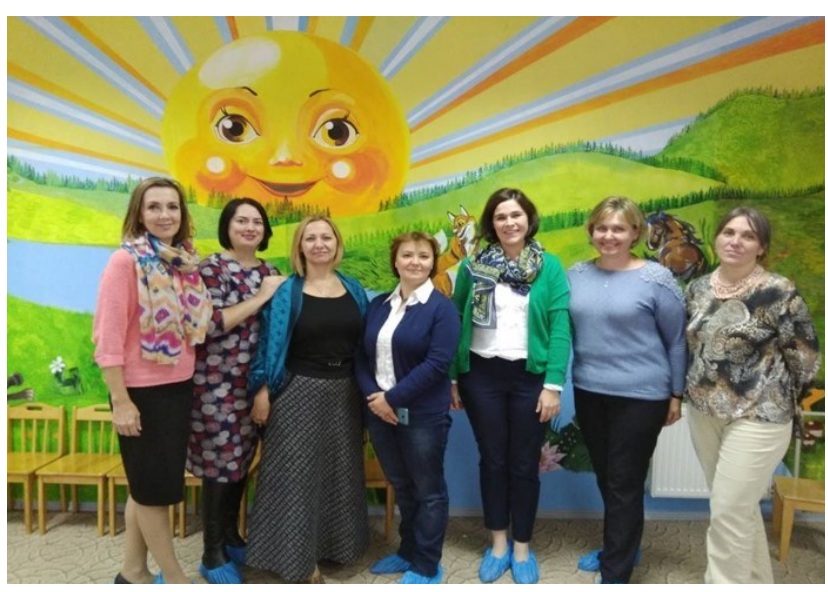




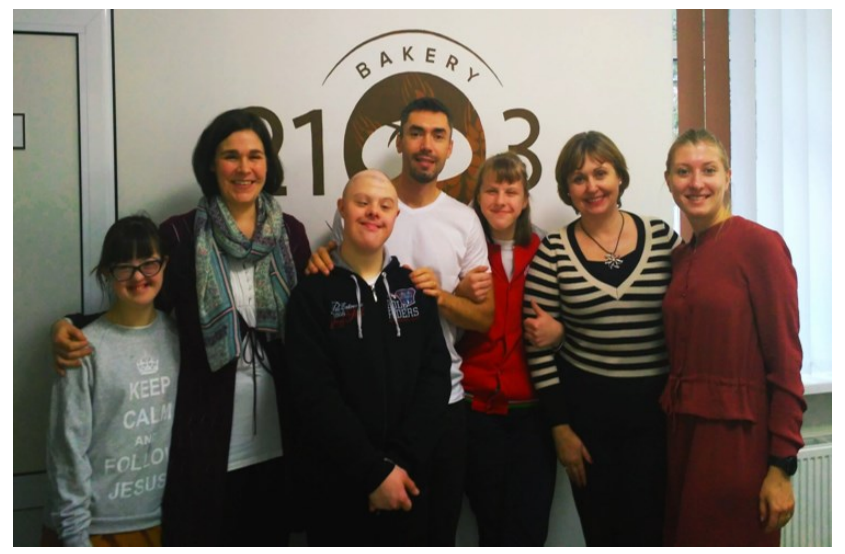

тури і освіти (Україна); українськими підприємствами і компаніями («Ашан», «Редісон» та ін.).

Практична значущість дослідження полягає у тому, що його результати використано при розробленні навчальних програм спеціальних закладів загальної середньої освіти та закладів із інклюзивним навчанням; розробленні діагностичного інструментарію вивчення стану психофізичного розвитку дітей з комплексними порушеннями розвитку; програмного забезпечення з основних навчальних предметів та комплексу корекційно-розвиткових занять з провідних напрямів (розвиток мовлення, соціально-побутове орієнтування, ритміка, лікувальна фізкультура) для дітей з інтелектуальними та комплексними порушеннями розвитку, призначених для практичного використання в освітньому та корекційно-розвивальному процесі спеціальних та інклюзивних закладів загальної середньої освіти. Отримані дані використовують практичні працівники при плануванні та проведенні уроків, а також - для розроблення відповідних методичних матеріалів.

Теоретичне значення дослідження полягає: у визнанні домінантності компетентнісного підходу до визначення та структуризації змісту предметів мовленнєвого, природничого, здоров'язберігального, предметно-практичного та соціальнопобутового циклу в освіті дітей з порушеннями інтелектуального розвитку; науковому обгрунтуванні методичних основ забезпечення корекційно-розвивальної спрямованості навчання учнів 3 інтелектуальними та комплексними порушеннями розвитку, що ґрунтується на підвищенні адаптивних можливостей дитини; зменшенні впливу дестабілізаційних чинників на формування особистості школяра; розвитку пізнавальної, мовленнєвої, сенсомоторної діяльності, особистісних здібностей учнів; визначенні нових методичних підходів до реалізації змісту навчання української мови, інтегрованих курсів «Навчання грамоти»,
«Я досліджую світ», «Мистецтво», «Технології»; фізичної культури, соціально-побутового орієнтування та корекційно-розвиткових занять.

Результати наукового дослідження «Науковометодичне забезпечення реалізації змісту навчання дітей з комплексними порушеннями розвитку» сприяють збагаченню теоретикометодичної бази освіти дітей з інтелектуальними та комплексними порушеннями розвитку з позицій компетентнісного підходу, що забезпечить підвищення результативності корекційнорозвивального впливу освітнього процесу та реалізацію потенційних психофізичних можливостей учнів.

Наукові результати апробовано на практиці експериментально перевірено ефективність оновленого змісту навчання учнів з інтелектуальними та комплексними порушеннями розвитку в контексті виконання Концепції НУШ. Перспективним $\epsilon$ подальше розроблення напрямів, методичних підходів допомоги дітям з інтелектуальними та комплексними порушеннями розвитку раннього, дошкільного та молодшого шкільного віку та їхнім родинам як провідної передумови подальшого розвитку та соціалізації дітей. Актуальними також $є$ дослідження, присвячені сучасним освітнім технологіям навчання учнів основної школи як складової системи професійно-трудової підготовки та самовизначення осіб із комплексними порушеннями в контексті реалізації концепції НУШ щодо формування життєвої компетентності учнів.

\section{СПИСОК ВИКОРИСТАНИХ ДЖЕРЕЛ}

Блеч, Г.О. (2018). Програма з корекційнорозвиткової роботи «Розвиток мовлення» для 14 класів спеціальних закладів загальної середньої освіти для дітей з інтелектуальними порушеннями. https://lib.iitta.gov.ua/711541/

Бобренко, І.В. (2018). Програма з корекційнорозвиткової роботи «Лікувальна фізкультура» для 14 класів спеціальних закладів загальної середньої освіти для дітей з інтелектуальними порушеннями. https://lib.iitta.gov.ua/711561/

Гладченко, І.В. (2018а). Програма з корекційнорозвиткової роботи "Театральна логоритміка» для 1-4 класів спеціальних закладів загальної середньої освіти для дітей з інтелектуальними порушеннями. https://lib.iitta.gov.ua/711460/

Гладченко, І.В. (2018b). Програма з корекційнорозвиткової роботи «Барабанотерапія» для 1-4 класів спеціальних закладів загальної середньої освіти для дітей з інтелектуальними порушеннями. https:// lib.iitta.gov.ua/711512/

Електронна бібліотека НАПН України. (n.d.). Інститут спеціальної педагогіки і психології імені Миколи 
Ярмаченка Начіональної академії педагогічних наук України. http://bit.ly/30Emxln

Закон України «Про освіту». (2017, 5 вересня). https://zakon.rada.gov.ua/laws/show/2145-19

Закон України "Про повну загальну середню освіmy». (2020, 16 січня). https://zakon.rada.gov.ua/laws/ show $/ 463-20$

Засенко, В.В., \& Прохоренко, Л.І. (2018). Нова українська школа - стратегія розвитку освіти дітей з особливими потребами. In N. Nyczkalo, J. Kunikowski, G. Wiezbicki (Eds), Nauka Edukacja Wychowanie i Praca (pp. 149-258). Warszawa-Siedlce

Інститут спеціальної педагогіки і психології імені Миколи Ярмаченка НАПН України. (2020, 13 листопада). Онлайн-семінар «Науково-методичні засади діяльносmi ІРЦ». http://ispukr.org.ua/?p=6275

Інститут спеціальної педагогіки і психології імені Миколи Ярмаченка НАПН України. (n.d.). Головна. http://ispukr.org.ua/

Інститут спеціальної педагогіки і психології імені М. Ярмаченка НАПН України. (n.d.). Головна [Facebook Page]. Facebook. https://www.facebook.com/ispukr/

Кабінет Міністрів України. (2016, 14 грудня). Про схвалення Кониепиії реалізації державної політики у сфері реформування загальної середньої освіти «Нова українська школа» на період до 2029 року. https://zakon.rada.gov.ua/laws/show/988-2016-p

Кремень, В.Г., Луговий, В.І., Топузов, О.М., Регейло, І.Ю., \& Базелюк, Н.В. (2020). Про виконання Програми спільної діяльності Міністерства освіти і науки України та Національної академії педагогічних наук України на 2017-2020 роки. Вісник Начіональної академії педагогічних наук України, 2(2). https://doi.org/10.37472/2707305X-2020-2-2-2-3

Міністерство освіти і науки України. (2014-2020). Корекційні програми. https://bit.ly/3pyLgla

Міністерство освіти і науки України. (2018-2020). Типові освітні програми. https://bit.ly/3dzMnoT

Міністерство освіти і науки України. (n.d.). Нова українська школа. https://mon.gov.ua/ua/tag/novaukrainska-shkola

Організація об'єднаних націй. (2006, 13 грудня). Конвенція про права осіб з інвалідністю. https:// zakon.rada.gov.ua/laws/show/995_g71

Сухіна, І.В. (2018). Гіперактивна дитина. Серія «/нклюзивне навчання». Харків: Видавництво «Ранок», ВГ «Кенгуру». https://lib.iitta.gov.ua/711316/

Трикоз, С.В. (2018). Програма 3 корекційнорозвиткової роботи «Розвиток психомоторики та сенсорних процесів» для 1-4 класів спеціальних закладів загальної середньої освіти для дітей з інтелектуа льними порушеннями. https://lib.iitta.gov.ua/711572/

Трикоз, С.В., \& Блеч, Г.О. (2018). Дитина з порушеннями інтелектуального розвитку. Серія «|нклюзивне навчання». Харків: Видавництво «Ранок», ВГ «Кенгуру». https://lib.iitta.gov.ua/711320/

Чеботарьова, О.В., Блеч, Г.О., Гладченко, І.В., Трикоз, С.В., \& Бобренко І.В. (2019). Типова освітня програма початкової освіти спеціальних закладів загальної середньої освіти для учнів 3 класу з порушеннями інтелектуального розвитку. https://lib.iitta.gov.ua/719177/

Чеботарьова, О.В. (2019). Реалізація компетентнісного підходу у навчанні школярів з порушеннями інте- лектуального розвитку. In Збірник матеріалів V Міжнародного конгресу зі спеціальної педагогіки, психології та реабілітології "Діти з особливими потребами в освітньому просторі», 10-11 жовтня 2019 р. м. Київ, Україна (с. 234-237). Чернігів: Симоненко O.I. https://lib.iitta.gov.ua/717876/

Чеботарьова, О.В. (2020). Сучасні технології навчання дітей з інтелектуальними порушеннями в Новій українській школі. In Збірник матеріалів IV Всеукраїнської науково-практичної конференції «Інновачійні підходи в освіті та реабілітації дітей із особливими освітніми потребами» (до 15-річчя ВГО "Українська асоціація корекційних педагогів»), м. Київ, Україна (с. 104-108). Національний педагогічний університет імені М.П. Драгоманова. https://lib.iitta.gov.ua/720527/

Чеботарьова, О.В., Блеч, Г.О., Бобренко, І.В., Гладченко, І.В., Мякушко, О.І., Трикоз, С.В., Сухіна, І.В., \& Ярмола, Н.А. (2019). Особливості реалізації компетентнісного підходу в освіті дітей з інтелектуальними порушеннями : навчально-методичний посібник. https://lib.iitta.gov.ua/718292/

Чеботарьова, О.В., Блеч, Г.О., Гладченко, І.В., Трикоз, С.В., \& Бобренко І.В. (2019). Типова освітня програма початкової освіти спеціальних закладів загальної середньої освіти для учнів 2 класу з порушеннями інтелектуального розвитку. https://lib.iitta.gov.ua/719176/

Чеботарьова, О.В., Блеч, Г.О., Гладченко, І.В., Трикоз, С.В., \& Бобренко І.В. (2020а). Типова освітня програма початкової освіти спеціальних закладів загальної середньої освіти для учнів 4 класів з інтелектуальними порушеннями. https://lib.iitta.gov.ua/722273/

Чеботарьова, О.В., Блеч, Г.О., Гладченко, І.В., Трикоз, С.В., \& Бобренко, І.В. (2020b). Критерії очінювання навчальних досягнень учнів початкових класів $з$ порушеннями інтелектуального розвитку : навчально-методичний посібник. https://lib.iitta.gov.ua/721883/

Чеботарьова, О.В., Блеч, Г.О., Гладченко, І.В., Трикоз, С.В., Бобренко, І.В., \& Ярмола, Н.А. (2019). Критерії очінювання навчальних досягнень учнів 5-10 класів з порушеннями інтелектуального розвитку : навчально-методичний посібник. https://lib.iitta.gov.ua/718297/

Чеботарьова, О.В., Блеч, Г.О., Гладченко, І.В., Трикоз, С.В., Сухіна, І.В., \& Ярмола, Н.А. (2018). Психологопедагогічний супровід навчання дітей з інтелектуальними порушеннями : навчально-методичний посібник. https://lib.iitta.gov.ua/722281/

Чеботарьова, О.В., Блеч, Г.О., Гладченко, І.В., Трикоз, С.В., Сухіна, І.В., Бобренко, І.В., Мякушко О.І. (2020). Порадник батькам: практичні рекомендації під час дистанційного навчання дітей з інтелектуальними порушеннями : навчально-методичний посібник. https://lib.iitta.gov.ua/721765/

Чеботарьова, О.В., Блеч, Г.О., Гладченко, І.В., Трикоз, С.В., Ярмола, Н.А., \& Бобренко І.В. (2018). Типова освітня програма початкової освіти спечіальних закладів загальної середньої освіти для учнів 1 класів з інтелектуальними порушеннями. https:// lib.iitta.gov.ua/712585/

Чеботарьова, О.В., Гладченко, І.В., Василенко-ван де Рей, А., \& Ліщук, Н.І. (2020). Дитина із синдромом Дауна. Серія «Інклюзивне навчання». Харків: Видавництво «Ранок», ВГ «Кенгуру». https:// lib.iitta.gov.ua/711322/ 
Чеботарьова, О.В., Коваль, Л.В., \& Данілавічютє, Е.А. (2018). Дитина із церебральним паралічем. Серія «ннклюзивне навчання». Харків: Видавництво «Ранок», ВГ «Кенгуру». https://lib.iitta.gov.ua/722101/

Чеботарьова, О.В. (2018). Програма з корекційнорозвиткової роботи «Азбука творчості» для 1-4 класів спеціальних закладів загальної середньої освіти для дітей з інтелектуальними порушеннями. https:// lib.iitta.gov.ua/711426/
Чеботарьова, О.В. (2018). Програма з корекційнорозвиткової роботи «Цікавий світ Монтессорі» для 1-4 класів спеціальних закладів загальної середньої освіти для дітей з інтелектуальними порушеннями. https://lib.iitta.gov.ua/711435/

Чеботарьова, О.В., Гладченко, І.В., \& Ярмола, Н.А. (2019). Основи діагностичної діяльності корекційного педагога в роботі з дітьми з комплексними порушеннями розвитку : методичні рекомендації. https:// lib.iitta.gov.ua/718307/

\section{SCIENTIFIC AND METHODOLOGICAL SUPPORT FOR IMPLEMENTING THE CONTENT OF CHILDREN WITH COMPLEX DEVELOPMENTAL DISABILITIES EDUCATION}

Scientific report at the meeting of the Presidium of the National Academy of Educational Sciences of Ukraine, February 18, 2021

\section{Olena Chebotarova}

PhD in Pedagogy, Senior Researcher, Head of the Department for Education of Children with Intellectual Disabilities, Mykola Yarmachenko Institute of Special Pedagogy and Psychology of the National Academy of Educational Sciences of Ukraine, Kyiv, Ukraine

Abstract. The main results of applied research on the scientific and methodological support for implementing the content of children with complex developmental disabilities education are enlightened in the report. It was conducted by the researchers of the Department for Education of Children with Intellectual Disabilities at Mykola Yarmachenko Institute of Special Pedagogy and Psychology of the National Academy of Educational Sciences of Ukraine during 20182020. The developed and tested in practice scientific and methodological manuals, textbooks, typical educational programs, typical correctional and developmental programs, diagnostic materials for studying the peculiarities of children with intellectual and complex disabilities development and learning are presented. Special attention is paid to the implementation of the research results in the practice of special and inclusive general secondary education institutions. The active collaboration of the Department with the Ministry of Education and Science of Ukraine in developing the scientific and methodological assurance for children with intellectual and complex disabilities education according to the New Ukrainian School concept is highlighted. Attention is focused on the results of cooperation in the international project "Perspective 21/3" concerning the socialization of pupils with intellectual disabilities, with public parents' organizations, dissemination of research and practical results during in-service teacher training, etc. The suggestions for further innovative studies in the sphere of children with intellectual disabilities education, including early childhood, preschool, and primary school age, are expressed.

Keywords: complex developmental disabilities; intellectual disabilities; content of education; scientific and methodological assurance; Department for Education of Children with Intellectual Disabilities; Mykola Yarmachenko Institute of Special Pedagogy and Psychology of NAES of Ukraine.

Дата публікації: 12 березня 2021 р. 